\title{
Masa Inkubasi Gejala Penyakit Hawar Daun Tanaman Kentang yang Diinduksi Ketahanannya oleh Jamur Antagonis Trichoderma viride
}

\author{
Susiana Purwantisari ${ }^{1}$, Achmadi Priyatmojo ${ }^{2}$, \\ Retno Peni Sancayaningsih ${ }^{3}$ dan Rina Sri Kasiamdari ${ }^{3}$ \\ 1 Departemen Biologi, Fakultas Sains dan Matematika, Universitas Diponegoro, Semarang \\ Jln Prof. Soedarto, SH,Semarang,50275, Telp: (024)7474754; Fax (024) 76480923 \\ 2 Fakultas Pertanian Universitas Gadjah Mada, Jl. Hortikultura Yogyakarta, Indonesia \\ 3 Fakultas Biologi Universitas Gadjah Mada, Jl. Sekip Utara Yogyakarta, Indonesia \\ Email :Susiana_purwantisari@yahoo.co.id
}

\begin{abstract}
Late blight disease caused by Phytophthora infestans, is probably the single most important disease of potatoes worldwide. Infected plants were quickly killed and were difficult for replanting, causing significant losses for the growers. Various control methods were examined including the use of biocontrol agents of Trichoderma spp. The biocontrol potential of Trichoderma viride against potato late blight pathogen, Phytophthora infestans, were studied under greenhouse conditions. The research objective was to determine the ability of biocontrol agents Trichoderma viride to delay late blight disease incidence on potato plants in the field. The in vivo experiment was carried out at potato land area located at BALITSA in Cikole Sub District, Lembang District and Bandung Regency. Completely Randomized Design was used with six treatment and five replicates. The treatment tested consist of control (without pathogen fungal and antagonists fungus application too), control (with pathogen fungal application and without antagonist fungal application), chemical fungicide application, antagonist fungal application 2 weeks before planting, application 1 week after planting and both application 2 weeks before and 1 week after planting. Result of the research showed that application of antagonists fungal could delay disease intensity until 14 days. These antagonist could be used as biological agents initials to control leaf blight disease.
\end{abstract}

Key words: Biological control, Potato late blight, Phytophthora infestans, Trichoderma viride

\begin{abstract}
Abstrak
Penyakit hawar daun oleh patogen Phytophthora infestans merupakan penyakit utama pada tanaman kentang yang dapat menurunkan produksi hingga $100 \%$, sehingga mengakibatkan kerugian yang nyata bagi para petani kentang. Penggunaan agensia hayati Trichoderma viride sebagai penginduksi ketahanan tanaman kentang terhadap penyakit hawar daun merupakan metode yang sangat potensial dilakukan. Tujuan penelitian ini adalah mengevaluasi penggunaan agensia hayati Trichoderma viride dalam menginduksi ketahanan tanaman kentang terhadap penundaan penyakit hawar daun pada penelitian di lapangan/ rumah kasa. Metode penelitian menggunakan penelitian eksperimental dengan pola penelitian rancangan acak lengkap dengan 6 perlakuan. Hasil penelitian menunjukkan bahwa aplikasi Trichoderma viride dapat menunda kemunculan penyakit hawar daun dibandingkan dengan kontrol dan fungisida. Aplikasi Trichoderma viride menunda penyakit hawar daun sampai 14 hari.
\end{abstract}

Kata kunci: Trichoderma viride, penyakit hawar daun, Phytophthora infestans, induksi ketahanan tanaman

\section{PENDAHULUAN}

Tanaman kentang merupakan komoditas hortikultura yang memegang peranan penting dalam perekonomian di Indonesia. Selain menunjang program diversifikasi pangan, umbi tanaman kentang juga menjadi bahan pangan alternatif pengganti beras karena mempunyai kandungan karbohidrat, protein dan lemak serta vitamin C yang cukup tinggi (Ashari, 1995; Suwarno, 2008). Sampai tahun 2012, Provinsi Jawa Tengah merupakan salah satu pusat produksi kentang dengan area pertanaman paling luas di Indonesia, yaitu 16.102 ha dengan produksi mencapai 252608 ton (BPS Jateng, 2013). Salah satu kendala utama dalam budidaya kentang adalah gangguan penyakit hawar daun/ late blight 
oleh patogen Phytophthora infestans disamping keterbatasan benih yang berkualitas. Kehilangan hasil akibat penyakit hawar daun tersebut dapat mencapai 100\% (Semangun, 2006: Ambarwati et al., 2009). Penyakit hawar daun sangat merusak dan sulit dikendalikan, karena $P$. infestans merupakan jamur patogen yang memiliki tingkat patogenisitas beragam. Keberagaman patogenisitas tersebut dapat terjadi karena jamur ini bersifat heterotalik. (Purwanti, 2002).

Metode alternatif yang sangat potensial dilakukan adalah pengendalian secara hayati menggunakan jamur yang bersifat antagonis terhadap patogen $P$. infestans tersebut yaitu jamur antagonis Trichoderma spp. (Cook and Baker, 1983; Latifah et al., 2011). Mekanisme penekanan jamur Trichoderma spp., selain bersifat hiperparasit dan mikoparasit, namun juga mampu menginduksi ketahanan tanaman inang terhadap potensi serangan patogen (Rifai, et. al., 1996; Agrios, 2005; Wahyuno et al., 2009; Sudantha et al., 2011). Pengendalian penyakit hawar daun tanaman kentang dengan induksi ketahanan (induced resistance) tanaman dengan jamur antagonis Trichoderma spp. merupakan bagian dari pengendalian hayati karena memanfaatkan mikroorganisme non patogenik sebagai penginduksi ketahanan tanaman tersebut.

Akibat adanya ketahanan terimbas oleh inokulasi agensia hayati, terjadilah pengurangan gejala penyakit dan perubahan faktor-faktor biokimiawi di dalam tanaman inang, yang menyebabkan tanaman tahan terhadap serangan patogen penyebab penyakit. Pengimbasan ketahanan dalam tanaman oleh agensia hayati tersebut, didasarkan atas pengaktifan potensi genetik ketahanan tanaman inang. Penelitian ini bertujuan untuk mengetahui ketahanan tanaman kentang terhadap penyakit hawar daun yang telah diinduksi oleh jamur antagonis Trichoderma viride. Ketahanan tanaman kentang terhadap penyakit hawar daun, salah satunya dapat diketahui dengan penundaan terjadinya gejala penyakit hawar daun. Gejala penyakit hawar daun dapat diketahui dengan mengamati saat munculnya bercak nekrotis pada tepi daun tanaman kentang untuk yang pertama kali setelah tanaman diinokulasi oleh patogen $P$. infestans tersebut. Penundaan gejala penyakit hawar daun adalah salah satu indikator ketahanan tanaman kentang karena induksi oleh agensia hayati. Masih banyak indikator-indikator ketahanan tanaman kentang yang lain seperti perubahan struktural atau peningkatan kandungan biokimiawi dalam jaringan tanaman oleh induksi agensia hayati tersebut.

Percobaan yang dilakukan di rumah kaca menunjukkan adanya penurunan perkecambahan sklerotia Rhyzoctonia. solani sebesar $88 \%$ dengan perlakuan bibit sebelum tanam dengan $T$. viride. Enzim B-(1,3) glucanase dihasilkan oleh jamur $T$. viride mampu menghancurkan miselia jamur Sclerotinia sclerotiorum. T. viride menghasilkan antibiotik serta berbagai enzim seperti eksoglukonase, endoglukonase, selobiase dan kitinase yang dapat menghancurkan dinding sel jamur patogen pada tanaman (Papavizas, 1985). Mekanisme perlindungan tanaman oleh $T$. viride tidak hanya melibatkan serangan terhadap patogen pengganggu, tetapi juga melibatkan produksi beberapa metabolit sekunder yang berfungsi meningkatkan pertumbuhan tanaman dan akar (Harman, 2006).

\section{BAHAN DAN METODE}

Penelitian dilakukan di kebun kentang Balai Penelitian Tanaman Sayuran (BALITSA), yang terletak di Desa Cikole, Kecamatan Lembang, Kota Bandung Provinsi Jawa Barat dengan ketinggian \pm 1200 meter di atas permukaan laut. Penelitian dilaksanakan pada bulan Maret sampai dengan bulan Juli 2013. Bibit kentang adalah varietas Granola (G2) yang merupakan varietas yang rentan terhadap penyakit hawar daun. Bibit kentang diperoleh dari Balai Benih Kentang BALITSA. Medium tanam kentang berupa campuran tanah dan kompos/pupuk kandang matang dengan perbandingan 3:1 selanjutnya dimasukkan ke dalam polybag dengan diameter 50 $\mathrm{cm}$. Medium tanah terlebih dahulu disterilkan secara fisik dengan sterilisator tanah (pengukus). Bibit kentang kemudian ditanam pada masingmasing polybag dengan jumlah satu bibit dalam satu polybag. Tanaman kentang dipelihara selama kurang lebih 4 bulan. Masa inkubasi adalah waktu antara saat inokulasi jamur patogen sampai timbulnya gejala awal penyakit hawar daun. Setelah inokulasi jamur patogen, pengamatan 
dilakukan setiap hari untuk mengetahui kapan munculnya gejala penyakit hawar daun untuk pertama kali (waktu inkubasi).

Penelitian menggunakan pola Rancangan Acak Lengkap (RAL) yang terdiri dari 6 perlakuan dan 6 ulangan. Uji percobaan penelitian di rumah kaca menggunakan metode Rancangan Acak Lengkap (RAL) dengan 6 (enam) perlakuan, yang masing-masing perlakuan diulang sebanyak 8 kali. Keenam perlakuan tersebut adalah: P1: Aplikasi jamur antagonis $T$. viride 2 minggu sebelum tanam bibit kentang (mst) dan infeksi jamur patogen $P$. infestans, (P2): Aplikasi jamur antagonis T. viride 1 minggu sesudah tanam kentang (msd) dan iinfeksi jamur patogen $P$. infestans. (P3): Aplikasi jamur antagonis $T$. viride $2 \mathrm{mst}$ dan $1 \mathrm{mst}$ serta infeksi jamur patogen $P$. infestans. (P3): Aplikasi fungisida sintetis berbahan aktif mankozeb (Dithane M-45) dan infeksi jamur patogen $P$. infestans. (P5): Tanpa inokulasi T. viride tanaman kentang namun diinfeksi patogen $P$. infestans (kontrol positif). (P6): Tanaman kentang yang tidak diaplikasi $T$. viride maupun tidak diinfeksi patogen P. infestans (kontrol negatif) (P6).

Isolat jamur antagonis $T$. viride diremajakan pada medium PDA selama 8 hari di dalam suhu ruang $\left(25^{\circ} \mathrm{C}\right)$, selanjutnya dihitung kepadatan konidianya sampai $10^{8}$ konidia/mL. Isolat patogen $P$. infestans juga ditumbuhkan pada medium V8 juice agar selama kurang lebih 9 hari di dalam inkubator pada suhu $18^{\circ} \mathrm{C}$. Selanjutnya sporangia yang telah tumbuh dipanen dengan cara dikerok pada permukaan medium V8 juice agar tersebut dengan glass rod. Sporangia kemudian dihitung kepadatannya sampai mencapai $10^{3}$ sporangia/mL. Penghitungan kepadatan konidium dan sporangia dilakukan dengan bantuan haemocytometer. Sebanyak $250 \mathrm{~mL}$ larutan suspensi konidia $T$. viride dengan kepadatan tersebut di atas dituang ke dalam tanah tempat tumbuh bibit kentang dengan perlakuan masingmasing. Selanjutnya pada umur tanaman kentang 30 hari, sebanyak $300 \mathrm{~mL}$ suspensi zoospore $P$. infestans dengan kepadatan zoospore $10^{6}$ juga diinokulasikan pada daun pada tanaman kentang yang telah berumur 30 hari kecuali pada perlakuan kontrol positif. Kelembaban udara relatif dijaga minimal sebesar $90 \%$ dan suhu udara relative diatur pada $20^{\circ} \mathrm{C}$.

\section{HASIL DAN PEMBAHASAN}

Masa inkubasi adalah waktu antara saat inokulasi patogen $P$. infestans sampai timbulnya gejala awal penyakit hawar daun. Tanaman kentang berumur 30 hari diinokulasi/ diinfeksi oleh patogen $P$. infestans kecuali pada perlakuan P6 (kontrol positif). Pengamatan tanaman dilakukan setiap hari untuk mengetahui kapan munculnya gejala penyakit hawar daun untuk pertama kali. Berdasarkan hasil analisis data secara statistik dan pengamatan secara morfologis pada habitus tanaman, diketahui bahwa aplikasi jamur antagonis $T$. viride dengan beberapa variasi perlakuan waktu aplikasi (P1, P2 dan P3) menunjukkan pengaruh yang nyata terhadap saat munculnya gejala penyakit hawar daun (masa inkubasi) pada tanaman kentang (Tabel 1).

Tabel 1. Rerata masa inkubasi penyakit hawar daun tanaman kentang oleh 6 perlakuan aplikasi Trichoderma viride (hari setelah inokulasi/ hsi)

\begin{tabular}{lc}
\hline Perlakuan & Masa Inkubasi (hsi) \\
\hline P1 & $16,11 \mathbf{a}$ \\
P2 & $13,77 \mathbf{~ b}$ \\
P3 & $13,16 \mathbf{b}$ \\
P4 & $2,7 \mathbf{c}$ \\
P5 & $2,17 \mathbf{c}$ \\
P6 & $0,00 \mathbf{d}$ \\
\hline
\end{tabular}

Angka-angka yang diikuti huruf yang sama pada kolom yang sama tidak berbeda nyata pada taraf 5\% Uji Jarak Berganda Duncan. P1: Aplikasi T. viride $2 \mathrm{mgg}$ sblm tnm (mst), P2:Aplikasi T. viride $2 \mathrm{mgg} \mathrm{ssdh}$ tnm (msd), P3: Aplikasi T. viride $2 \mathrm{mgg}$ mst dan $1 \mathrm{mgg}$ msd, P4: Aplikasi fungisida sintetis, P5: Tanpa aplikasi T. viride (kontrol positif) dan P6: Tanpa aplikasi T. viride dan jamur patogen (kontrol negatif). 
Gejala pertama yang terlihat dari penyakit hawar daun di lapang adalah terdapatnya bercak luka nekrotis pada tepi daun dengan bentuk yang tidak beraturan yang berwarna gelap/ hitam kecoklatan. Gejala selanjutnya, bercak nekrotis akan meluas pada seluruh daun, tangkai daun dan seluruh tanaman apabila keadaan lingkungan (suhu yang rendah dan kelembaban udara yang tinggi) mendukung perkembangan penyakit hawar daun tersebut. Demikian juga yang disampaikan oleh Agrios (2005), bahwa kondisi lingkungan yang mendukung perkembangan patogen $P$. infestans akan mempercepat masa inkubasi penyakit, sehingga jamur patogen akan lebih cepat untuk menginfeksi tanaman.

Patogen $P$. infestans mempunyai virulensi dan patogenitas yang tinggi jika dalam keadaan lingkungan yang sesuai untuk perkembangannya. Rata-rata suhu udara harian $20^{\circ} \mathrm{C}$ dan kelembaban udara di atas 90\% (lihat Lampiran 1, 2 dan 3) pada saat penelitian, menyebabkan jamur patogen $P$. infestans mempunyai virulensi dan patogenitas yang tinggi. Hal tersebut sesuai dengan apa yang telah diteliti oleh Iskandar (1997) bahwa perkecambahan sporangium $P$. infestans terjadi pada suhu $3^{0}-26^{0} \mathrm{C}$ dan kelembaban relatif di atas $90 \%$. Hal ini juga mengakibatkan penyakit hawar daun lebih cepat berkembang.

Pada Tabel 1 dapat dilihat bahwa aplikasi $T$. viride dengan beberapa variasi waktu perlakuan aplikasi (P1, P2 dan P3) dapat memperpanjang masa inkubasi hingga enam belas (16) hsi dan berbeda nyata dengan perlakuan fungisida dan kontrol (P4 dan P5) yaitu 2 hsi. Masa inkubasi penyakit hawar daun pada tanaman kentang yang diaplikasi $T$. viride berturut-turut adalah $16,11 \mathrm{hsi}$ (P1); 13, 77 hsi (P2) dan 13, 16 hsi (P3), sedangkan masa inkubasi pada perlakuan fungisida dan kontrol (tanpa aplikasi T. viride berturut-turut adalah 2.77 hsi (P4) dan 2, 17 hsi (P5). Semua perlakuan dengan aplikasi $T$. viride berbeda secara nyata dengan perlakuan kontrol. Gejala penyakit hawar daun pada tanaman kentang muncul pertama kali pada perlakuan P5 (tanaman tanpa aplikasi jamur antagonis $T$. viride) yaitu sebesar 2, $17 \mathrm{hsi}$. Kemunculan gejala penyakit hawar daun pada perlakuan P5 ini tidak berbeda secara signifikan dengan pada perlakuan P4 (perlakuan dengan aplikasi Dithane-M45) yaitu sebesar 2, 72 hsi.

Aplikasi jamur antagonis T. viride $2 \mathrm{mst}$ (perlakuan P1), aplikasi $T$. viride $1 \mathrm{msd}$ (P2) dan aplikasi $T$. viride 2 mst dan 1 msd (perlakuan P3) mampu memperlambat masa inkubasi gejala penyakit hawar daun. Adanya penundaan munculnya gejala penyakit hawar daun pada ketiga perlakuan tersebut kemungkinan disebabkan tanaman telah mempunyai ketahanan secara preventif terhadap serangan jamur patogen P.infestans sehingga perkembangan penyakit hawar daun tertunda lebih lama daripada tanaman yang tidak diaplikasi jamur antagonis (perlakuan P4 dan P5). Hal ini sesuai dengan yang telah diteliti oleh Manohara (2008), bahwa hasil pengamatan enam minggu setelah inokulasi $P$. capsici, tidak ditemukannya gejala busuk pangkal batang pada tanaman lada yang telah diinfestasikan $T$. harzianum 14 hari lebih awal penanaman bibit lada.

Aplikasi T. viride mampu memperpanjang periode inkubasi dan menekan perkembangan bercak nekrotis penyakit hawar daun oleh infeksi $P$. infestans sehingga keparahan penyakit tidak berlanjut. Hal tersebut kemungkinan disebabkan adanya pengaruh induksi ketahanan struktural tanaman kentang oleh aplikasi agensia antagonis T. viride. Ketahanan struktural tanaman kentang dapat berupa penguatan dinding sel tanaman oleh peningkatan akumulasi lignin. Lignin adalah lapisan yang menyusun dinding sel jaringan tanaman sebagai struktur penghalang masuknya patogen ke dalam tanaman. Penguatan dinding sel oleh lignifikasi menyebabkan zoospore $P$. infestans tidak mampu melakukan penetrasi ke dalam sel daun tanaman serta tidak mampu melakukan perkecambahan meskipun keadaan lingkungan sangat kondusif untuk pertumbuhan patogen.

Seperti yang disampaikan oleh Koike (1997), bahwa perkecambahan spora patogen akan terhambat dan tidak dapat menginfeksi tanaman dengan adanya induksi jamur antagonis pemacu pertumbuhan tanaman yang dapat meningkatkan lignifikasi pada sel daun tanaman. Peningkatkan produksi senyawa antifungi tertentu dan peningkatan sintesis enzim hidrolitik oleh tanaman 
yang terinduksi juga telah dipandang sebagai mekanisme utama terhadap pengurangan penyakit. Pembentukan penylpropanoid telah diamati menyebabkan peningkatan sintesis senyawa lignin dan fenol. Apabila tanaman diinduksi oleh jamur antagonis, deposisi lignin meningkat sepanjang dinding sel tanaman untuk melindungi penetrasi lebih lanjut oleh patogen. Peningkatan formasi lignin ini telah diimplikasikan sebagai suatu mekanisme utama untuk resistensi sistemik teriduksi oleh karena resisten terhadap degradasi sebagian besar mikroorganisme (Meera et al., 1994).

Trichoderma spp. mempunyai mekanisme biokontrol dengan menginduksi ketahanan tanaman terhadap serangan patogen. Beberapa strain Trichoderma spp. membentuk kolonisasi yang kuat, tahan lama pada permukaan akar, dan menembus ke dalam epidermis. Trichoderma spp. juga memproduksi dan melepaskan berbagai senyawa kimia metabolit sekunder ke dalam jaringan tanaman sehingga dapat menginduksi respon resistensi lokal (pada jaringan tertentu tempat agen penginduksi diaplikasikan) dan secara sistemik (seluruh bagian tanaman) (Harman et al., 2004). Menurut Heil and Bostok (2002) dalam Syahri (2011), induksi ketahanan tanaman dapat terjadi melalui dua cara yaitu dengan memproduksi secara langsung patogenesisrelatedprotein $(\mathrm{PR})$ protein dan fitoaleksin sebagai akibat serangan mikroorganisme patogenik. Cara yang kedua yaitu dengan menghasilkan komponen enzim selulase yang terdiri dari enzim eksoglukanase $(\beta-1.4$ glikanhidrolase), dan sellubiase ( $\beta$-glukosidase) yang mampu merusak dinding sel jamur patogen secara langsung.

Jamur antagonis $T$. viride mampu menginduksi ketahanan tanaman kentang terhadap serangan jamur patogen penyebab penyakit hawar daun secara sistemik sehingga jamur patogen membutuhkan waktu yang lebih lama dalam menginfeksi sel daun tanaman kentang. Pada penelitian yang telah dilakukan, agen penginduksi $T$. viride dan jamur patogen $P$. infestans diinokulasikan pada tempat yang berbeda sehingga tidak ada kemungkinan adanya efek antagonisme secara langsung. Terinduksinya ketahanan tanaman kentang ini kemungkinan juga karena terlepasnya elisitor yang dapat memicu pengaktifan sistim pertahanan tanaman kentang secara sistemik. Elisitor tersebut terdapat pada dinding sel miselium atau spora jamur antagonis $T$. viride. Dinding sel jamur $T$. viride mengandung senyawa glukanase dan polisakarida (selulosa) yang berpotensi untuk memicu produksi fitoaleksin yang berperan pada ketahanan tanaman kentang itu sendiri (Lyon et al., 1995).

Selain itu, di dalam elisitor juga terkandung metabolit yang dihasilkan jamur antagonis $T$. viride. Koike et al. (2001) melaporkan bahwa jamur -jamur pemacu pertumbuhan tanaman (PGPF) seperti $T$. viride dapat menghasilkan metabolit yang dapat berperan secagai elisitor yang mengaktifkan sistim pertahanan tanaman mentimun, sehingga lebih tahan terhadap infeksi jamur patogen Colletotrichum orbiculare. Bahkan jauh sebelumnya, Cook and Baker (1983) juga mengatakan bahwa senyawa gliotoksin dan viridin yang dihasilkan $T$. viride . bersifat menghambat perkembangan jamur patogen tanaman. Jamur antagonis diketahui juga menghasilkan zat fitoaleksin yang berperan dalam mekanisme ketahanan jaringan tanaman. Perlambatan serangan patogen $P$. infestans pada perlakuan P1, P2 dan P3 inilah yang menunjukkan adanya kemampuan dan mekanisme $T$. viride dalam menekan serangan infeksi dari jamur patogen $P$. infestans.

Lebih cepatnya kemunculan gejala penyakit hawar daun pada perlakuan P4 dan P5 menunjukkan bahwa pada perlakuan P4 dan P5 ini tanaman tidak mempunyai perlindungan preventif untuk menghambat serangan jamur patogen $P$. infestans sehingga penyakit hawar daun lebih cepat berkembang. Tidak adanya aplikasi $T$. viride sebelum tanam bibit kentang menyebabkan tanaman tidak mempunyai mekanisme ketahanan tanaman secara sistemik untuk menekan perkembangan penyakit hawar daun oleh serangan patogen $P$. infestans. Dari hasil pengamatan saat muncul gejala penyakit hawar daun tanaman kentang, dapat disimpulkan bahwa aplikasi $T$. viride pada perlakuan $\mathrm{P} 1, \mathrm{P} 2$ dan $\mathrm{P} 3$ efektif dalam menghambat munculnya gejala penyakit hawar daun dan terdapat interaksi yang nyata antara waktu aplikasi $T$. viride terhadap waktu munculnya gejala penyakit hawar. 


\section{KESIMPULAN}

1. Aplikasi jamur antagonis Trichoderma viride 2 minggu sebelum tanam, tanaman kentang mampu menunda kemunculan gejala penyakit hawar daun hinggga 14 hari.

2. Mekanisme ketahanan tanaman kentang oleh induksi jamur antagonis Trichoderma viride 2 minggu sebelum tanam dibuktikan dengan penundaan gejala penyakit hawar daun tanaman kentang.

3. Aplikasi Trichoderma viride 2 minggu sebelum tanam mampu menginduksi ketahanan tanaman kentang dengan menunda kemunculan terjadinya gejala penyakit hawar daun.

\section{UCAPAN TERIMA KASIH}

Penulis menyampaikan penghargaan dan terima kasih yang sebesar-besarnya kepada segenap staf Laboratorium Bakteri dan Cendawan Balai Penelitian Tanaman Sayuran (BALITSA) di Desa Cikole Kecamatan Lembang, Kota Bandung Provinsi Jawa Barat yang telah banyak membantu terlaksananya penelitian ini.

\section{DAFTAR PUSTAKA}

Agrios, GN. 2005. Plant Pathology, Fifth edition. Elsevier Academic Press:USA.

Ambarwati AD, Agus P, M. Herman, SM Sumaraow dan H Aswidinnoor. 2009. Analisis integrasi dan segregasi gen ketahanan terhadap hawar daun pada progeny $\mathrm{F} 1$ hasil persilangan tanaman kentang transgenik dengan non transgenik. Jurnal Agro Biogen 5(1). Hlm. 25-31.

Ashari, S. 1995. Hortikultura aspek Budidaya. Universitas Indonesia Press. Jakarta.

BPS Provinsi Jawa Tengah. 2015. Statistik Pertanian Hortikultura Jawa Tengah 20122014.

http://jateng.bps.go.id/Publikasi/view/id/313. Diunduh tanggal 15 April 2016.

Cook, RJ and KF Baker. 1983. The Nature and Practice of Biological Control of Plant Pathogens. APS Press The American Phytopathological Society. St. Paul, Minnesota.

Harman GE, ChR Howell, A Viterbo, I Chet and M Lorito. 2004. Trichoderma Species
Opportunistic, Avirulent Plant Symbionts. Nat Rev. 2:43-56.

Iskandar, YS., 1997. Peranan Agens Antagonis Pseudomonas spp. Kelompok Fluorescens Terhadap Perkembangan Penyakit Hawar Daun Kentang (Phytophthora infestans(Mont.) de Bary. http://www.studentpaper.ub.ac.id/78525925/ . Pada tanggal 4 April 2012.

Koike N, M Hyakumachi, K Kageyama, S Tsuyumu and $\mathrm{N}$ Doke. 2001. Induction of systemic resistance in cucumber against several diseases by plant growth-promoting fungi: lignification and superoxide generation. Eur J Plant Pathol. 107:523533.

DOI: http://dx.doi.org/10.1023/A:1011203826805

Latifah, A, Kustantinah dan L Soesanto. 2011. Pemanfaatan beberapa isolat Trichoderma sebagai agensia pengendali hayati penyakit layu Fusarium pada bawang merah in planta. Eugenia 17(2): 86-94.

Manohara, D. 2008. Pengaruh kelengasan tanah terhadap daya bertahan hidup Trichoderma harzianum dan efikasinya terhadap Phytophthora capsici. Bul. Littro. XIX (2) : 145-153

Meera, MS, MB Silvana, K Kageyama and M Kyakumachi. 1994. Plant growth promoting fungi from zoysiagrass rhizosphere as potensial inducer of systemic resistance in cucumbers. Phytopathology 84:1399- 1406.

Papavizas, G.C. 1985. Trichoderma harzianum and Gliocladium: Biology, Ecology and Potensial for Biological Control of Soiborne Diseases. Laboratory Plant Protection Institut Agriculture Research Service, US Department of Agriculture Research, Beltsville, Maryland.

Purwanti, H. 2002. Penyakit Hawar Daun (Phytophthora infestans (Mont.) de Bary) pada

Kentang \& Tomat: Identifikasi Permasalahan di Indonesia. Buletin

Agrobio Deptan.

Bogor.

Rifai, MA., S Mujim dan TN Aeny. 1996. Pengaruh Lama Investasi Trichoderma viride Terhadap Intensitas Serangan 
Pythium sp. Pada Kedelai. Jurnal Penelitian Pertama VII : $8: 20-25$.

Semangun, H. 2007. Penyakit - Penyakit Tanaman Hortikultura. UGM Press : Yogyakarta.

Soesanto, L. 2008. Pengantar Pengendalian Hayati Penyakit Tumbuhan. Raja Grafindo Persada, Jakarta.

Sudantha, I. M. dan NML Ernawati. 2014. Peran Jamur Endofit Trichoderma spp. Untuk Meningkatkan Ketahanan Terinduksi Bibit Pisang Terhadap Penyakit Layu Fusarium. Agroteksos. Vol. 24: 3. Hal. 145-152.
Suwahyono, U. 2000. Biopestisida. Penebar Swadaya. Jakarta.

Suwarno, W.B. 2008. Sistem pembenihan kentang di Indonesia. http://www.situshijau.co.id diakses pada 5 September 2012).

Syahri. 2011. Potensi pemanfaatan cendawan Trichoderma spp. sebagai agens pengendali penyakit tanaman di lahan rawa lebak. Balai pengkajian teknologi pertanian (BPTP). Sumatera selatan. 